\title{
RELIABILITY ANALYSIS OF DISTRIBUTOR VALVE OF AIR BRAKE SYSTEM FOR FREIGHT WAGON
}

\author{
UDC 621-192:621.22
}

\author{
Erdinč Rakipovski ${ }^{1^{*}, 2}$, Dragan Milčić ${ }^{1}$ \\ ${ }^{1}$ Faculty of Mechanical Engineering, University of Niš, Serbia \\ ${ }^{2}$ Public Transport Enterprise - Skopje, Skopje, North Macedonia
}

\begin{abstract}
The results of distributor valve fault tree analysis are presented in this paper. A brief description and procedure of fault tree analysis are given in the first two parts. The reliability of the distributor valve is extremely important for the functioning of the air brake system. For this reason, reliability analysis of distributor valve based on the time to failure is shown in this paper. The distributor valve should react to changes in brake pipe pressure and provide the corresponding pressure in the brake cylinder.
\end{abstract}

Key words: reliability, fault tree analysis, braking system, distributor valve, freight wagon

\section{INTRODUCTION}

The brake has an essential function for speed reduction and train braking within the shortest time possible. In terms of safety, it is more important that the railway vehicle is able to stop if necessary, rather than move. Therefore, the brake is considered as an indispensable part of a railway vehicle. It is impossible to drive any vehicle without other components, but if the brakes are not functioning properly, the vehicles must not be used in traffic [1].

When it comes to railway brake equipment, railways give special importance to the development and maintenance of brake equipment. In order to use braking equipment in trains used in various railway networks in international traffic, the International Union of Railways (UIC) defines the common rules for the design and construction of brake systems [2,3].

The regulations of the UIC that apply to the brake are covered in the announcements UIC 540 - 549.

Reliability is an important index for measuring product safety, quality and performance. The new method is technically based on the strengthening and damaging features of

Received August 13, 2019 / Accepted September 23, 2019

Corresponding author: Erdinč Rakipovski, PhD Candidate

Public Transport Enterprise - Skopje, Aleksandar Makedonski Blvd. 10, 1000 Skopje North Macedonia

E-mail: erdincrakip@gmail.com 
vehicle components under a loading spectrum whilst combining dynamic strength equations with the residual strength of vehicle components [4]. The system reliability level matches the requirement for differential systems, which considerably reduces cost, as demonstrated by using the stress-strength interference and low-load strengthening models $[5,6]$. The rationality of reliability reallocation is verified according to the subsystem importance coefficient [7,8]. Based on the stress-strength interference model, automobile welding structure reliability has been studied and discussed with the theories of probability and reliability [9, 10]. A generalized reliability analysis model, which considers multiple competing causes, is highly necessary $[11,12]$.

Freight wagons are the main transport means which provide transportation of goods and earn the main income of each railway administration. The railway success depends on their mobility (validity and contemporariness) and massive commercialization, so it is not surprising that the Railway Administration through International Union of Railways tackles the issues of modernization, standardization and unification of wagons preventively. Brakes are the components of freight wagons which are extremely significant for wagon exploitation in domestic and international traffic, and also represent an essential factor of safe travel.

For failure analysis of elements of technical systems, the most commonly used method is Fault Tree Analysis - FTA. The basis of FTA is to convert physical systems into structural logic diagrams. The FTA method was developed in the 1960s in the US with the aim to analyse the reliability and security of systems in military technology. From the first stages of development until today, FTA has found application in reliability analysis of different technical systems. This method is particularly suitable for reliability analysis of systems in which failures lead to disastrous consequences for humans and the environment. If we define the cause of failure, we can evaluate the maintainability and develop the plan for maintenance of technical systems. In addition, FTA can serve as a diagnostic tool for determining the most likely causes of the resulting failure. In this paper, we described an analysis of potential failure modes of freight wagon distributor valve, which uses compressed air. For a detailed analysis of the causes and failure modes, it is necessary to know the structure and the function of the constituent elements of distributor valve.

\section{FTA METHOD FOR DistribUtOR VALVE OF THE AIR BRAKE SYSTEM OF FrEIGHT WAGONS}

In order to make reliability analysis of a technical system with a FTA method, a definition should be given in order to establish the boundaries and objectives of the system. The top event of the fault tree, depending on the analyzed system may be general (in the form of a system failure), or specific (if it includes some failures of the system or its components) [20, 21].

In this paper, the distributor valve type Mh3f HBG 310 has been analyzed.

Distributor valve (Fig.1), as the basic unit, is equipped with automatic releaser, as well as the limiter pressure of the brake cylinder. The introduction of automatic releaser, under the obligations of UIC and RIV, facilitate the exploitation of staff in handling releasing device. Now, it is enough to pull the release handle and the overcharged air installations will be automatically discharged, based on a different pressure between the main and the working chamber $[2,3]$. 


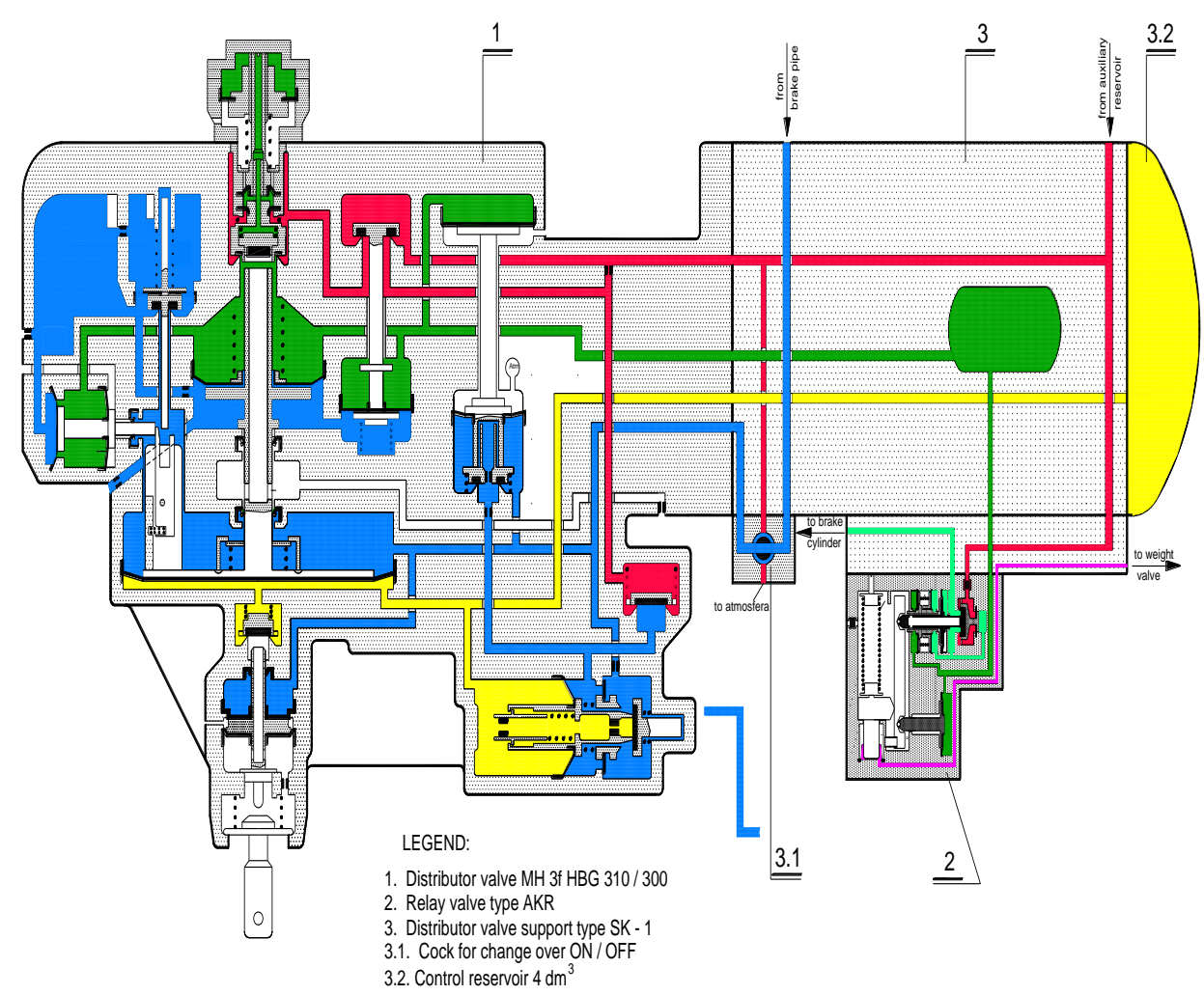

Fig. 1 Distributor valve type Mh3f HBG 310.

By incorporating pressure limiter in the brake cylinder of the distributor valve, in spite of high pressure in the main chamber, the working chamber and the auxiliary reservoir, the brake cylinder always gets the nominal working pressure and brake power does not exceed the calculated value.

Otherwise, high pressure increases brake force, which has negative impact on the wheels, and creates flat places or other damages to the wheels.

Before fault tree analysis, the reviewers need to examine the system in detail from the standpoint of structure, mode of operation and the relation between the constituent elements [31, 32]. Fault tree analysis in technical systems is done by using symbols for events, logic gates and connection between them. For the events, different symbols are used, which indicate that there are complex or basic initiating events. Rectangles are used for complex events. The most commonly used symbol for basic events is a circle, which indicates the state of elements of the system caused by its characteristics, whereas a diamond indicates an undeveloped event. Logical symbols from the fault tree signify mutual causality and correlation of events at lower and higher levels. For example, in an "OR" logic gate, the output event occurs when at least one of the input events occurs. In an "AND" logic gate, the output event occurs only if all input events occur $[17,18]$.

The transfer symbols which are in the form of triangles with identification mark in the form of letters inside them, allow the formation of complex fault trees in the form of the 
top event tree and number of sub-trees [19]. When the fault tree is completed, it is systematically analyzed in order to understand the logic of relating events and provide a better insight into the different states of the system.

After the fault tree analysis, which depends on the FTA method applied, a qualitative and/or quantitative analysis can be made. Based on the study and the results of the fault tree analysis, corrective measures are suggested with the aim to eliminate all defects or proposae alternative solutions.

a) AND circuit - produces an output event only if all input events occur simultaneously.

b) OR circuit - produces an output event only if all input events occur.

The analytical failure scheme should be as simple as possible and in line with the complexity of the system. When building a logic progression, one should start from the unwanted to the top event. The scheme fault tree should be logical. Also, it is not necessary to develop unusual events whose likelihood of occurrence is very small $[14,15,16]$. Quantitative phase for formation of fault tree scheme is developed if there is information of likelihood for various events [30].

The main events in the tree are selected to be statistically independent events, i.e. the realization of one event does not affect the probability of occurrence of the second event [25]. For quantitative calculations, the following two theorems of probability theory are used:

a) a theorem of probability of the sum of dissenting events. The probability to encounter one, no matter which of the two events A and B are mutually excluded (Fig. 2), i.e. when the appearance of one excludes simultaneous appearance of another is equal to the sum of the probabilities of these events:

$$
P(\mathrm{~A}+\mathrm{B})=P(\mathrm{~A})+P(\mathrm{~B})
$$

If the events $\mathrm{A}$ and $\mathrm{B}$ are not excluded, it will be:

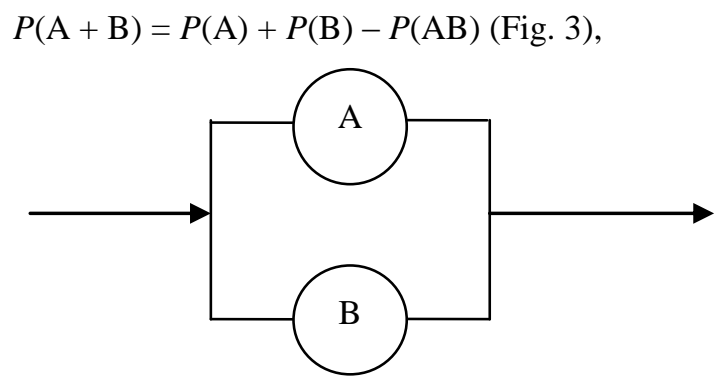

Fig. 2 Events A and B, connection in parallel

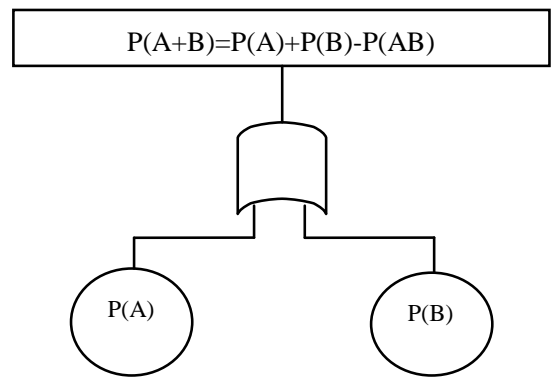

Fig. 3 Logic gate OR 
b) a theorem of probability of product of independent events. The probability of the joint occurrence of two independent events A and B, i.e. if the appearance of one of them does not affect the likelihood of the second, it is equal to the product the probability of each of these events:

$$
P(\mathrm{AB})=P(\mathrm{~A}) P(\mathrm{~B})(\text { Fig. } 4)
$$

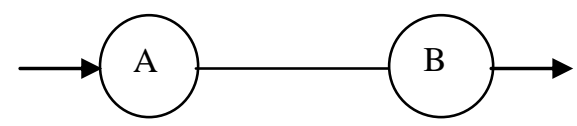

Fig. 4 Events A and B, connection in a series

which follows

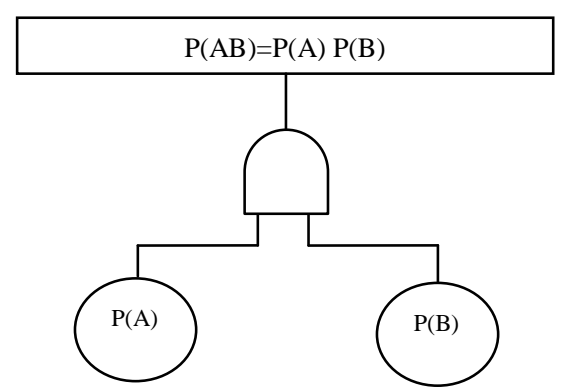

Fig. 5 Logic gate AND

- In case of the OR circuit likelihood of events, the output is the sum of the probability of the entrance.

- The probability that the result will be such that it will occur at the exit and the circuit is the product of the probability of all input events.

The previous analysis, as it has been said is true only in the case when events included into the scheme of the fault tree are mutually excluded, i.e. when one or only one output can occur with a single action. In this case, the relation (3) and (4) can be directly applied. When the events are not mutually excluded, one must make a correction by subtracting the probability $\mathrm{P}(\mathrm{AB})$ according to $(3 \mathrm{a})$. This correction is usually irrelevant because it is a value of small order.

\section{FAULT TREE FOR DISTRIBUTOR VALVE}

At the beginning of the fault tree analysis, the problem of defining the top event appeared. It will be greatly taken in consideration for most of the potential failure modes of elements. In addition, safety regulations require the use of automatic control and management system, which stop the distributor valve in certain situations [22]. The correct functionality of number of components only affects the ability to work. Furthermore, malfunction or misalignment of the assembly leads to partial failure of distributor valve, or a reduction in its efficiency. Because of all the above stated, failure analysis of distributor 
valve was done in a way in which many independent failure trees for different top events have been formed [23].

\section{A. Fault tree for the top event "Failure of distributor valve"}

Termination of work of the distributor valve can be the result of an automatic or a manual disconnection by the operator. Fault tree for the peak event "Failure of distributor valve" is shown in Figure 6 and 7. Automatic control of the operation and a distributor valve which has stopped refer to the current disconnection from the locomotive in the case: a low pressure in the distributor valve, a leak in number of valves, misalignment of certain segments, auxiliary inexhaustible reservoir of sensitivity, decrease pressure mains, gradual braking, emptying the working chamber through the automatic release valve [13]. Termination of work of the distributor valve shall be made by the operator unless the ongoing work noise is repetitive (flat places) or the operator feels strong vibrations [24, 26].

Table 1 Failures and the corresponding fault causes of the distributor valve

\begin{tabular}{|c|c|c|c|c|c|}
\hline $\begin{array}{l}\text { Component } \\
\text { name }\end{array}$ & Function & $\begin{array}{l}\text { Failure } \\
\text { causes }\end{array}$ & Component & $\begin{array}{c}\text { Failure Effe } \\
\text { Subassembly }\end{array}$ & Unit \\
\hline $\begin{array}{c}\text { Seal } \\
\varnothing 73 / 84 \times 1 \\
\text { rubber }\end{array}$ & $\begin{array}{l}\text { Provide sealing } \\
\text { between braking } \\
\text { cylinder and } \\
\text { atmosphere }\end{array}$ & $\begin{array}{l}\text { Improper } \\
\text { material } \\
\text { quality }\end{array}$ & $\begin{array}{l}\text { Decreased } \\
\text { function }\end{array}$ & $\begin{array}{l}\text { Decreased } \\
\text { function }\end{array}$ & $\begin{array}{c}\text { Decreased } \\
\text { pressure in } \\
\text { braking cylinders }\end{array}$ \\
\hline $\begin{array}{l}\text { O-ring } \\
\text { rubber }\end{array}$ & $\begin{array}{l}\text { Provide sealing } \\
\text { between valve } \\
\text { seat and housing }\end{array}$ & $\begin{array}{l}\text { Improper } \\
\text { material } \\
\text { quality }\end{array}$ & $\begin{array}{l}\text { Decreased } \\
\text { function }\end{array}$ & No effect & No effect \\
\hline $\begin{array}{l}\text { Diaphragm } \\
\text { rubber }\end{array}$ & $\begin{array}{l}\text { Provide sealing } \\
\text { between braking } \\
\text { cylinder and } \\
\text { atmosphere }\end{array}$ & $\begin{array}{l}\text { Improper } \\
\text { material } \\
\text { quality }\end{array}$ & $\begin{array}{l}\text { Decreased or } \\
\text { lost function }\end{array}$ & $\begin{array}{l}\text { Disturbed } \\
\text { function }\end{array}$ & $\begin{array}{c}\text { Degradation- } \\
\text { Decreased } \\
\text { pressure in } \\
\text { braking cylinder }\end{array}$ \\
\hline $\begin{array}{l}\text { Diaphragm } \\
\text { rubber }\end{array}$ & $\begin{array}{l}\text { Provide sealing } \\
\text { between brake } \\
\text { pipe and } \\
\text { atmosphere }\end{array}$ & $\begin{array}{l}\text { Improper } \\
\text { material } \\
\text { quality }\end{array}$ & $\begin{array}{l}\text { Decreased or } \\
\text { lost function }\end{array}$ & $\begin{array}{c}\text { Minor } \\
\text { degradation }\end{array}$ & $\begin{array}{l}\text { No significant } \\
\text { effect } \\
\text { Increased } \\
\text { compressor } \\
\text { working cycles }\end{array}$ \\
\hline Spring & Valve opening & $\begin{array}{l}\text { Improper } \\
\text { material } \\
\text { quality }\end{array}$ & Lost function & $\begin{array}{l}\text { Lost } \\
\text { function }\end{array}$ & $\begin{array}{l}\text { Risk of outage- } \\
\text { significant } \\
\text { discrepancy }\end{array}$ \\
\hline Cover & $\begin{array}{l}\text { Provide valve } \\
\text { sealing and } \\
\text { diaphragm } \\
\text { positioning }\end{array}$ & Unscrewing & $\begin{array}{l}\text { Decreased } \\
\text { function }\end{array}$ & $\begin{array}{l}\text { Decreased } \\
\text { function }\end{array}$ & $\begin{array}{l}\text { Decreased } \\
\text { pressure in brake } \\
\text { cylinder. } \\
\text { Increased } \\
\text { compressor work }\end{array}$ \\
\hline Valve body & $\begin{array}{l}\text { Supports valve } \\
\text { insert and } \\
\text { diaphragm }\end{array}$ & $\begin{array}{l}\text { Improper } \\
\text { dimensions }\end{array}$ & $\begin{array}{l}\text { Improper } \\
\text { function }\end{array}$ & $\begin{array}{l}\text { Diaphragm } \\
\text { dysfunction } \\
\text { or damage } \\
\text { can be } \\
\text { caused }\end{array}$ & $\begin{array}{c}\text { Decreased } \\
\text { pressure in brake } \\
\text { pipe. Increased } \\
\text { compressor work }\end{array}$ \\
\hline Cover & $\begin{array}{l}\text { Valve body } \\
\text { guiding and } \\
\text { positioning }\end{array}$ & $\begin{array}{l}\text { Improper } \\
\text { dimensions }\end{array}$ & $\begin{array}{l}\text { Improper } \\
\text { function }\end{array}$ & $\begin{array}{l}\text { Lost } \\
\text { function }\end{array}$ & $\begin{array}{c}\text { Risk of power } \\
\text { outage }\end{array}$ \\
\hline
\end{tabular}




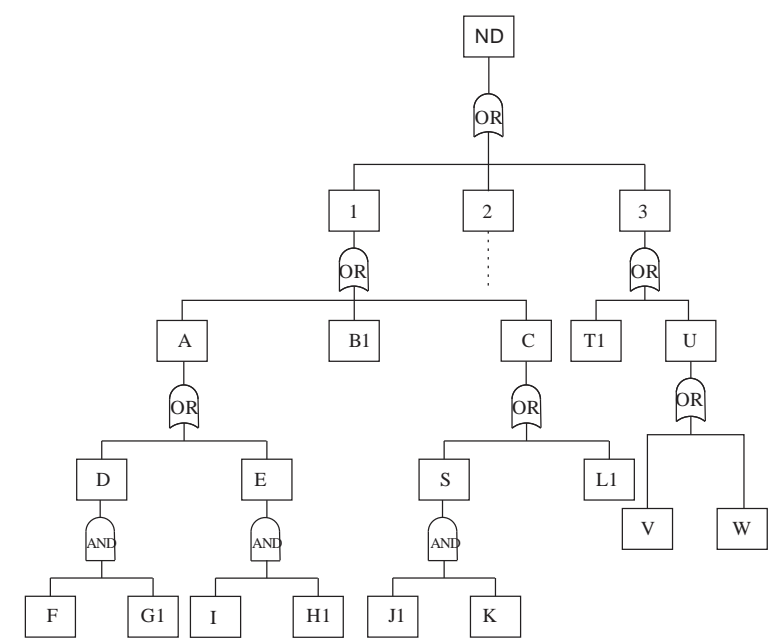

Fig. 6 Fault tree for distributor valve

Data of probability of unwanted events are taken from Wabtec MZT distributor valve (MH3f HBG310/300-Wabtec MZT AD Skopje) and are given in Table 2.

Table 2 Probability of unwanted events of distributor valve

\begin{tabular}{rlcc}
\hline No. & Description & Designation & $\begin{array}{c}\text { Probability of } \\
\text { unwanted events }\end{array}$ \\
\hline 1 & Improper regulation & $\mathrm{B}_{1}$ & 0,000943 \\
2 & Clogged nozzles & $\mathrm{F}$ & 0,000251 \\
3 & Clogged valves & $\mathrm{G}_{1}$ & 0,000614 \\
4 & The reaction started too early & $\mathrm{H}_{1}$ & 0,000769 \\
5 & A faulty pressure regulator, a late reaction & $\mathrm{I}$ & 0,000921 \\
6 & The non return valve is not fully closed & $\mathrm{J}_{1}$ & 0,000911 \\
7 & There was no discernible change in pressure & $\mathrm{K}_{1}$ & 0,00282 \\
8 & At the entrance - insufficient pressure & $\mathrm{L}_{1}$ & 0,00025 \\
9 & Do not be maintained properly flow & $\mathrm{N}_{1}$ & 0,00922 \\
10 & Clogged filters & $\mathrm{P}$ & 0,000911 \\
11 & Impurities in pipe installation & $\mathrm{Q}_{1}$ & 0,00464 \\
12 & Output air is not clean & $\mathrm{R}$ & 0,000331 \\
13 & Seal 22x10x7mm leaks & $\mathrm{S}_{1}$ & 0,002899 \\
14 & Improperly releasing & $\mathrm{T}_{1}$ & 0,000869 \\
15 & The problem in air systems - a leak & $\mathrm{V}$ & 0,0001077 \\
16 & Dirt/deposits of oil from the locomotive & $\mathrm{W}$ & 0,00301 \\
& (working fluid-Air pressure) & & \\
\hline
\end{tabular}




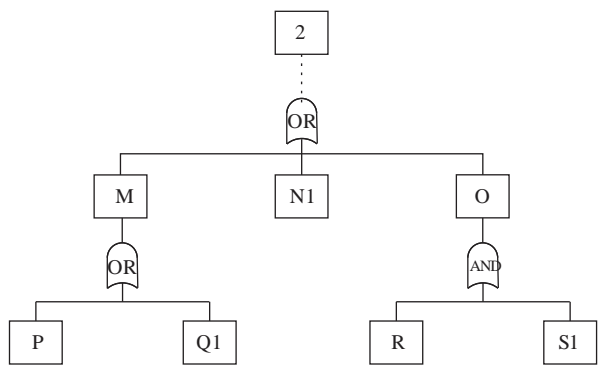

Fig. 7 Fault tree for distributor valve

The probability of unwanted events - failure of distributor valve $P_{N D}$ :

$$
P_{N D}=P_{1}+P_{2}+P_{3}
$$

$P_{1}$ - improperly time of braking

$P_{2}$ - improperly releasing time

$P_{3}$ - unregulated time of braking and releasing

$$
\begin{gathered}
P_{1}=P_{A}+P_{B 1}+P_{C} \\
P_{A}=P_{D}+P_{E}=P_{F} \cdot P_{G 1}+P_{H 1} \cdot P_{I} \\
P_{C}=P_{S}+P_{L 1}=P_{J 1} \cdot P_{K}+P_{L 1} \\
P_{1}=P_{F} \cdot P_{G 1}+P_{H 1} \cdot P_{I}+P_{B 1}+P_{J 1} \cdot P_{K}+P_{L 1}=0,0012 \\
P_{2}=P_{M}+P_{O}+P_{N 1} \\
P_{M}=P_{P}+P_{Q 1} \\
P_{3}=P_{T 1}+P_{V}+P_{W} \\
P_{2}=P_{P}+P_{Q 1}+P_{R} \cdot P_{S 1}+P_{N 1}=0,0148 \\
P_{3}=P_{T 1}+P_{U} \\
P_{U}=P_{V}+P_{W} \\
P_{3}=P_{T 1}+P_{V}+P_{W}=0,00399 \\
P_{N D}=P_{1}+P_{2}+P_{3}=0,0012+0,0148+0,00399 \\
P_{N D}=0,01999
\end{gathered}
$$

The reliability of distributor valve:

$$
R=1-P_{N D}=1-0,01999=0,98001
$$

\section{RELIABILITY ANALYSIS OF DISTRIBUTOR VALVE}

In the research, the reliability of components and systems is based on the analysis of empirical data reliability from exploitation monitoring of different technical systems. One of the ultimate goals of reliability analysis is to determine the theoretical distribution of random variables in technical systems. More precisely, the highest goal is to determine which distribution is most suitable for the empirical data, i.e., which distribution can best interpretate the results. 
To determine the theoretical distribution, graphical and analytical methods are used. Graphical methods are very simple and are often used in engineering practice. Features of Microsoft Excel allow easy application of both methods [29]. Graphical method for determining the distribution law and relevant parameters is done using the probability paper, which is a simple way can be generated in Microsoft Excel. A point with coordinates is entered in the probability chart $\left[t_{i}, F\left(t_{i}\right)=t_{i}, \mathrm{MR}\left(t_{i}\right)\right]$. Number of points equal the number of observed elements $n$. If the plotted points can be approximated by a straight line, a supposed model of distribution law can be obtained. Otherwise, the hypothesis of the law distribution is rejected. Using graphical methods can validate the model law distribution and estimate the parameters of the distribution [27, 28].

The best known analytical methods for determining parameters of the distribution are:

- Method of least squares (Regression analyze);

- The method of torque;

- The Maxiumum-Likelihood-Method.

Time to failure seals of distributor valve obtained by monitoring are presented in 7 intervals and given in Table 3.

Table 3 Exploatation of failure seals of distributor valve

\begin{tabular}{lccccccc}
\hline$i$ & 1 & 2 & 3 & 4 & 5 & 6 & 7 \\
\hline$t, \mathrm{~km}$ & 416000 & 434000 & 452000 & 470000 & 488000 & 506000 & 524000 \\
$N(\Delta t)$ & 4 & 9 & 17 & 10 & 7 & 3 & 2 \\
$N(t)$ & 4 & 13 & 30 & 40 & 47 & 50 & 52 \\
$M R, \%$ & 7,0611 & 24,2366 & 56,6794 & 75,7634 & 89,1221 & 94,8473 & 98,6641 \\
\hline
\end{tabular}

The failure times plotted on Weibull probability chart (Fig. 8) fall in a fairly linear fashion, indicating that our choice of the two-parameter Weibull distribution was valid.

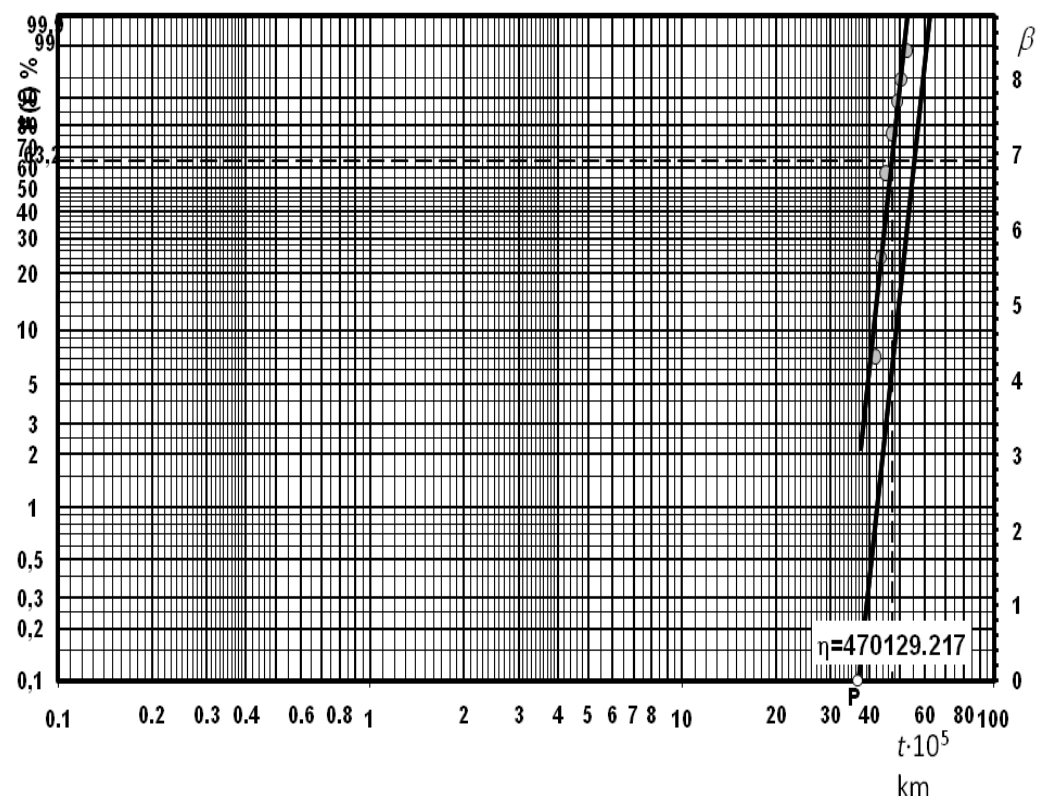

Fig. 8 Weibull distribution probability chart 
From the Weibull distribution probability chart, these parameters can be determined:

$\beta=16,819, \eta=470129,21$, therefore, the law reliability Weibull distribution can be written as:

$$
R(t)=e^{-\left(\frac{t}{470129}\right)^{16.8}}
$$

Also, the failure times plotted on normal probability paper fall in a fairly linear fashion, indicating that our choice of the normally (Gaussian) distributed with parameters: mean $m$ and standard deviation $\sigma-(m, \sigma)=(453801,7,30024,2) \mathrm{km}$.

\section{CONCLUSION}

Reliability of distributor valve is extremely important for the functioning of the air brake system. Reliability analysis of distributor valve of braking system wagons is determined on the basis of empirical failure data. The analysis was made on the basis of data obtained by exploitation monitoring in the field.

A software for reliability analysis was developed at the Faculty of Mechanical Engineering in Nis. This software has performed a reliability analysis of a scheduler of braking system wagons.

Reliability analysis indicates that the failure data of the distributor valve seals can be described with standard normal distribution and Weibull distribution. For initial hypothesis, normal distribution and Weibull distribution, statistical test KolmogorovSmirnov test or d $\alpha$-test were performed. Fault tree of distributor valve allows a detailed analysis of the observed system from the point of failure occurrence, establishing causal links between the failure of the assembly in different levels of affiliation, recording the largest number of potential failure modes of the constituent elements, and forming a block diagram of reliability, etc. With detailed analysis of differences in the structure and functioning, the formed fault tree of distributor valve can be used for failure analysis of other variants of distributor valves. Durability, reliability and economy of distributor valve largely depend on the proper operation and maintenance.

Monitoring and measuring the parameters of functioning is crucial for early detection of defects in the distributor valve. In this way, the information for maintenance activities can be obtained, which can greatly contribute to the elimination of causes.

\section{REFERENCES}

1. Jegadeeshwaran, R. \& Sugumaran, V.: Fault diagnosis of hydraulic brake system using statistical features and support vector machines. Mechanical Systems and Signal Processing 52(1): 436-446, 2015.

2. Technical specification for interoperability relating to the infrastructure subsystem of the rail system in the European Union. (No. 1299/2014/EU). European Railway Agency, 2014.

3. Technical specifications for the interoperability of the European railway system (EU 1302/2014). European Railway Agency, 2014.

4. Zheng, S.L. \& Lu, X.: Lightweight design of vehicle components based on strengthening effects of lowamplitude loads below fatigue limit. Fatigue and Fracture of Engineering Materials Structures 35(3): 269$277,2012$.

5. Xie, W., Liao, H.T. \& Jin, T.D.: Maximizing system availability through joint decision on component redundancy and spares inventory. European Journal of Operational Research 11(237): 164-176, 2014. 
6. Liu, C.H. \& Huang, H.: An interval analysis for the mesco ductile fracture, Key Engineering Materials 2(324): 971-974, 2006.

7. Huang, X. \& Zhang, Y.: A probability estimation method for reliability analysis using mapped Gegenbauer polynomials. Proceedings of the Institution of Mechanical Engineers, Part O, Journal of Risk and Reliability 228(1): 72-82, 2014.

8. Liu, C.H. \& Chen, Q.: Interval analysis of fuzzy-random heat conduction in the composite tubes. Applied Mathematics and Mechanics 10(26): 1312-1318, 2005.

9. Allella, F., Chiodo, E. \& Lauria, D.: Optimal reliability allocation under uncertain conditions with application to hybrid electric vehicle design. International Journal of Quality and Reliability Management 22(6): 626-641, 2004

10. Song, S., Coit, D.W., Feng, Q. \& Peng, H.: Reliability analysis for multi-component systems subject to multiple dependent competing failure processes, Reliability. IEEE Transactions 63(1): 331-345, 2014.

11. Wu, J.N. \& Yan, S.Z.: An approach to system reliability prediction for mechanical equipment using fuzzy reasoning Petri net. Journal of Risk and Reliability 1(228): 39-51, 2014.

12. Liu, X.T., Zheng, S.L., Feng, J., Huang, H., Chu, J. \& Zhao, L.H.: Reliability analysis and evaluation of automobile welding structure. Quality and Reliability Engineering International 30(8): 1293-1300, 2014.

13. Lei Liu, Xintian Lion, Xiaolan Wang, Yanson Wang, Chuanchang Li: Reliability analysis and evaluation of a brake system based on completing risks. Journal of Engineering Research, Kuwait University, 2017.

14. Mijajlović, M., Milčić, D.: Analiza fazi pouzdanosti mašinskih sistema, IMK-14 Istraživanje i razvoj. Časopis instituta IMK “14. Oktobar” Kruševac, Godina XV , Broj (30-31), 1-2. s. 107-114, 2009.

15. Milčić, D.: Pouzdanost mašinskih sistema, Univerzitet u Nišu, Mašinski fakultet Niš, 2005.

16. Milčić, D.: Mijajlović, M., Pouzdanost mašinskih sistema - Zbirka rešenih zadataka. Mašinski falkultet Univerziteta u Nišu, Niš, 2008.

17. Milčić, D., Veljanović, D.: Softver za analizu pouzdanosti mašinskih delova i sistema. Naučno-stručni skup IRMES '06, Banjaluka-Mrakovica, s. 411-416, 2006.

18. Milčić, D., Mijajlović, M., Veljanović, D.: Analysis Reliability Software, 8th International Conference „Research and development in mechanical industry“ RaDMI, Užice, 2008.

19. Barlow R. E., Proschan F.: Statistical Theory of Reliability and Life Testing Probability Models, Holt, Rinehart and Winston, Inc., New York, 1975.

20. Lazor J. D.: Failure mode and effects analysis (FMEA) and Fault tree analysis (FTA) (Success tree analysis STA), In Handbook of Reliability Engineering and Management, McGraw-Hill, pp. 6.1-6.46, 1995.

21. Xu, R., Che, J.G., Yang, Z.B. \& Zuo, X.Y.: The fault tree analysis and its application in the system reliability analysis, Command Control \& Simulation 2(32): 112-115, 2010.

22. Ćatić D.: Metode pouzdanosti mašinskih sistema, Univerzitetski udžbenik, Mašinski fakultet u Kragujevcu, Kragujevac, 2009.

23. Tu, J.L., Duan, R.X. \& Dong, D.C.: An approach for construction of fault trees using rough set and fuzzy clustering algorithm, Applied Mechanics and Materials 11(35):186-191, 2010

24. Popov, A., Stojkov, N.: Documentation, catalogues and maintenance manuals of distributor valve from Wabtec MZT in Skopje, Republic of Macedonia, 2004.

25. Wang, J.D. \& Liu, T.S.: A component behavioural model for automatic fault tree construction, Reliability Engineering and System Safety 42(1): 87-100, 1993.

26. Sugumaran, V., Muralidharan, V. \& Ramachandran, K.I.: Feature selection using decision tree and classification through proximal support vector machine for fault diagnostics of roller bearing, Mechanical Systems and Signal Processing 21(2): 930-942, 2006.

27. Liu, X.T., Zheng, S.L., Feng, J., Huang, H., Chu, J. \& Zhao, L.H.: Reliability analysis and evaluation of automobile welding structure, Quality and Reliability Engineering International 30(8): 1293-1300, 2014.

28. Chen, T., Zheng, S.L., Luo, H.W., Liu, X.T. \& Feng, J.Z.: Reliability analysis of multiple causes of failure in presence of independent competing risks, Quality and Reliability Engineering International 32(2): 363-372, 2016

29. W Peng, H Z Huang, Y Li: Life cycle reliability assessment of new products - A Bayesian model updating approach, Reliability Engineering \& System Safety, 112(112): 109-119, 2013.

30. Vetoshkin A.G.: Reliability of technical systems and technogenic risk, Tutorial, Penza, 154. (in Russian), 2003.

31. Fumeo, E., Oneto, L., \& Anguita, D.: Condition based maintenance in railway transportation systems based on big data streaming analysis, Procedia Computer Science, 53, 437-446, 2015.

32. Thaduri, A., Galar, D., \& Kumar, U.: Railway assets: a potential domain for big data analytics, Procedia Computer Science, 53, 457-467, 2015. 


\section{ANALIZA POUZDANOSTI DISTRIBUTIVNOG VENTILA VAZDUŠNOG KOČIONOG SISTEMA NA TERETNOM VAGONU}

U radu su predstavljeni rezultati analize stabla grešaka na primeru distributivnog ventila. U prva dva dela dat je kratak opis i postupak analize stabala grešaka. Pouzdanost distributivnog ventila je izuzetno važan faktor za funkcionisanje sistema vazdušnih kočnica. Analiza pouzdanosti distributivnog ventila na osnovu podataka o vremenu između grešaka je prikazana u radu. Zadatak distributivnog ventila je da precizno reaguje na promenu pritiska u kočionoj cevi i obezbedi odgovarajući pritisak u kočionom cilindru.

Ključne reči: pouzdanost, analiza stabla grešaka, kočioni sistem, distributivni ventil, teretni vagon 